\title{
The Distinctiveness of Entrepreneurship in Transition Economies
}

\begin{abstract}
This paper is concerned with the distinctiveness of entrepreneurship and small business development in countries that are at different stages of transformation to market based economies. Following a discussion of the potential relevance of selected conceptualisations of entrepreneurship to transition conditions, the authors present original empirical data referring to the characteristics of entrepreneurs and their businesses from countries at different stages of market reform. Distinctive features of entrepreneurial behaviour identified reflect the unstable and hostile nature of the external environment and the scarcity of key resources, particularly capital. In an unstable and weakly structured environment, informal networks often play a key role in helping entrepreneurs to mobilise resources, win orders and cope with the constraints imposed by highly bureaucratic structures and often unfriendly officials. Moreover, the social context inherited from the former socialist period appears to affect both the attitudes and behaviour of entrepreneurs and the attitudes of society at large towards entrepreneurship.
\end{abstract}

\section{Introduction}

One of the issues facing Central and Eastern European countries in the transformation from centrally planned into market economies is the need to develop a private business sector, allowing entrepreneurs to create their own businesses. One question that arises in this respect concerns the nature of entrepreneurship under transition conditions and the extent to which it is distinctive

\section{David Smallbone}

Centre for Enterprise and

Economic Development Research

Middlesex University Business School

Hendon, NW4 4BT, U.K.

E-mail:d.smallbone@mdx.ac.uk

\section{Friederike Welter}

Rhine-Westphalia Institute for Economic Research (RWI)

Hohenzollernstr. 1-3

45128 Essen, Germany

E-mail:welter@rwi-essen.de compared with mature market economies, in which external environmental conditions are likely to be more stable and where there is a stronger recent tradition and experience of entrepreneurial activity. This paper considers the characteristics of entrepreneurs in transition economies and the circumstances in which they start up businesses.

At the firm level, transformation involves a shift from public to private sector ownership, which can occur either through the direct privatisation of former state owned enterprises or through the creation of completely new businesses. As a consequence, features such as the pace of new venture creation, the qualitative characteristics of entrepreneurs and the businesses that are created, the types of barrier they experience and the extent to which businesses are able to grow, may be seen as a barometer indicating how quickly the process of market reform is occurring.

The second element in the transformation process is the liberalisation of markets, where central administration of prices is replaced by market mechanisms, which involves an increase in market opportunities as well as in the level of competition. The third element involves the creation of market institutions, such as banks, other financial intermediaries and business and training support services, which are an integral part of the external environment for business development in mature market economies. Within the transformation process there are three major tasks for entrepreneurs: to assist in privatising and restructuring state-owned enterprises; helping to transform the distorted and monopolistic industrial structure of the former centrally planned economies; and establishing a private enterprise sector that includes small and medium sized busi- 
nesses (d'Andrea Tyson et al., 1994). This paper is concerned with the last of these tasks.

At the same time, it is important to recognise that transformation is much more than just an economic process. It also involves fundamental social changes as a one party state is replaced with a democratic system that is broadly based: "At an early stage of transformation particularly, the development of the SME sector . . . becomes one of the most effective instruments in the reorientation of social awareness ... Without liberating social awareness, the emergence of the private sector and a market economy are impossible" (Piasecki, 1995).

The rest of the paper consists of three main parts and a conclusion. The next section considers the potential relevance of existing conceptualisations of entrepreneurship to the specific circumstances represented by transition conditions. This is followed by an empirically based discussion of the characteristics of entrepreneurs and their businesses, drawing on results from a number of large scale surveys and selected case studies, undertaken by the authors. The third section is specifically concerned with the role of government as an influence on the nature and extent of entrepreneurial activity.

\section{Conceptualising entrepreneurship under transition conditions}

\section{The inheritance from the socialist period}

One question that arises in countries that until ten years ago were operating under a centrally planned system, concerns the potential of entrepreneurial activities during the socialist period to "breed capitalism" (Kornai, 1992). Although in Central and Eastern European countries private entrepreneurship lost its major role with the introduction of a centrally planned economic system, different forms of private entrepreneurship co-existed beside state ownership and entrepreneurship within state enterprises during the socialist period. In this regard, we can distinguish between the formal and the grey economy (consisting of the second and the illegal economy), whose "boundaries" frequently changed following political trends of liberalising and restricting private ownership and entrepreneurship (Welter, 1996a).
The formal economy included state enterprises, co-operatives and legalised private businesses such as craft enterprises in Poland or the so-called business work partnerships in Hungary. Here, since 1982, state employees could rent machinery or space from their employer to collectively produce their own products and services, although these private initiatives eventually became working brigades for state enterprises performing overtime work (Laky, 1985). The term "second economy" refers to any form of unlicensed but tolerated private entrepreneurial activities, including unlicensed activities in the private sector that were not officially recorded, as well as the clandestine use of state property (e.g., raw materials, machines, labour, services) for private business activities (Dallago, 1990). It can also be applied to the so-called "parallel circuits" of state firms and co-operatives that were motivated by the search of official enterprises for ways to meet planning targets and in the Soviet system created the "tolkachi", who were employees of state enterprises trying to secure external resources (Kerblay, 1977). In other words, entrepreneurial behaviour within state owned enterprises during the communist period was a necessary response to the constant shortage of materials. Finally, during the socialist period the illegal economy was made up of quasi-criminal activities within state enterprises (bribes, theft of resources) and also criminal private activities. However, in some countries (such as the former Czechoslovakia and the former Soviet republics) the illegal economy actually included any kind of private business activity. Even though the transformation process changed the rules for these entrepreneurs, some forms of entrepreneurship survived, which merged into the new private business sector, thereby constituting a distinctive experience of entrepreneurship, which was brought into the transition period.

Both state and private entrepreneurship that existed under socialism have provided a "seedbed" for small business activity during the transition period, in both the formal and informal economy. Entrepreneurship within state organisations contributed to the development of the so-called nomenclatura businesses in some countries during the transition period. Many directors and managers of state-owned enterprises as well as former politicians (the nomenclatura) have used their "parallel 
circuits" to privatise "their" enterprises or to establish new businesses (Dallago, 1997; Kusnezova, 1999; Lageman, 1995). The Soviet "Komsomol economy" with a number of business organisations established within the youth organisation under socialism is one example (Gustafson, 1999); the "spontaneous privatisation" that occurred in Hungary in 1988/89 (Frydman et al., 1998) was another source of nomenclatura entrepreneurs.

Formerly legal private enterprises such as craft enterprises in Poland or private businesses in the form of co-operatives that emerged in the late eighties in the Soviet Union (Chepurenko, 1998), continued to exist during the transition period, although their entrepreneurs often experienced difficulties in adjusting to the requirements of a market economy. Entrepreneurship that was tolerated during the former socialist period (which in the Czech and Slovak Republic also included illegal private entrepreneurship) mainly manifested itself during the transition period in the large number of people who registered new businesses once legislation abolished the legal and administrative barriers to private firms, enabling them to operate on an equal basis with state owned companies (Grabowski, 1993; Kuczi and Vajda, 1992). In countries such as Poland and Hungary, this occurred during the so-called initial phase of development of entrepreneurship in the early 1980s (Piasecki and Rogut, 1993), although in the former Soviet republics this happened later, starting with the law on co-operatives in 1988 (OECD/CCET, 1998). In those transition economies with a strong pre-war tradition of private entrepreneurship (such as Poland or Hungary) a number of entrepreneurs during the transition period originated from former entrepreneurial families that had either been self-employed in the second economy, or had occupied leading positions in state enterprises during the socialist period (Szelenyi, 1988).

In this regard, it is important to stress the differences in the starting points from which private enterprise has developed during the transition period in different countries, as well as differences in the processes that have operated during the transformation period. Entrepreneurship appears to have developed more quickly in countries where reforms proceeded smoothly and quickly (Mugler, 2000) and where there has been a strong pre- socialist industrial tradition. For example, in the former Czechoslovakia industrialisation and private entrepreneurship go back to the beginning of the 19th century (Benacek, 1997) which apparently favoured the quick development of entrepreneurship after socialism. On the other hand, in Russia, which was an essentially agrarian society prior to the socialist period, the state played a stronger role in the development of entrepreneurship (Ageev et al., 1995; Paradis, 1998). For example, at the beginning of the 20th century the Russian government tried to introduce entrepreneurship into the Russian economy by providing entrepreneurs with subsidies and donations, thus creating "bureaucratic entrepreneurship" (Kusnezova, 1999, p. 59).

\section{Different forms of entrepreneurship}

As in mature market economies, entrepreneurship is reflected in different types of business enterprise, although the particular forms and processes that have emerged in the former socialist countries may have features that are specific to transition conditions. Taking the entrepreneurial heritage in transition countries into account, we can distinguish between small business ownership, informal businesses and nomenclatura enterprises.

Self-employment and part-time businesses play an important role as forms of entrepreneurship in transition countries (Arzeni, 1996). Self employment provides a means of "self help" support for many former employees of state owned enterprises, who have either lost their jobs through restructuring in state owned firms, or have been forced to take leave. In order to counteract the growth of official unemployment, state owned firms often offer "administrative leave" to some employees, which is usually unpaid and without redundancy compensation. Nevertheless, many employees prefer this form of leave which allows them to officially keep their job and possibly draw some pension benefits. Many of these workers on administrative leave act as smallscale entrepreneurs, setting up their own part-time business as a means of generating income to survive, often operating at least partly in the informal sector (Malle, 1996). Whilst the details may be specific to the transition context, it may be suggested that the effects of this phenomenon has certain 


\section{Entrepreneurship and Context}

similarities with the model of small firm development described by Storey and Johnson (1987) as the Birmingham (U.K.) Model, in which selfemployment and small business ownership is seen essentially as a response to industrial decline and a contraction of alternative employment opportunities in mature market economies.

However, such factors have led some writers to adopt a negative stance with respect to small enterprise development under transition conditions. For example, in assessing the role of small businesses in transition economies, Scase (1997) distinguishes between "entrepreneurship" on the one hand, which refers to a person's commitment to capital accumulation and business growth, and "proprietorship" on the other, which refers to the ownership of property and other assets that may be used to realise profits but are not utilised for the longer term processes of capital accumulation. Scase emphasises that "proprietors" are more likely to consume any surplus that is generated rather than re-invest it in their businesses. He argues that it is "proprietors" rather than entrepreneurs which account for the majority of small businesses that are established in transition economies, as individuals strive to protect themselves from the uncertainties characteristic of emerging market economies, by generating cash flows that can be consumed for raising general living standards rather than for business expansion.

Whilst Scase is right to draw attention to the fact that only a minority of small business owners can be considered "entrepreneurs" in the classical sense, as he recognises himself, this is not a characteristic that is confined to economies in transition (Scase and Goffee, 1982). One of the consistent themes emerging from the western literature on SME development is the need to recognise the variety of motives of those who start and run small businesses, which can include lifestyle as well as financial motives. As a consequence, not all SME owners are aiming to grow their businesses (Curran, 1986), reflecting instead a variety of artisan, managerial and entrepreneurial identities (Stanworth and Curran, 1976). Moreover, it must be emphasised that SME development in a transition context is more than an economic process. As Scase himself recognises, the emergence of a stratum of small traders in transition economies is part of the social transformation contributing to wider consumer choice and the emergence of a middle class. As far as economic development is concerned, the point to stress is that the role of SMEs varies at different stages of the transformation process as well as in different national contexts. However, it may be that the proprietorship, which Scase emphasises is a more common condition in the early stages of transition, or in countries where market reforms have not been properly installed, becomes relatively less important in countries at a more advanced stage of transformation to a market economy.

One of the distinctive forms of entrepreneurship in transition economies (particularly in the former Soviet republics, but also in the early stages of transition in Hungary and the Czech Republic, e.g. Benacek, 1997) is represented by the so-called "nomenclatura" businesses, where political influence is used for private gain by protecting market niches and acting as a mechanism for resource mobilisation. This form of entrepreneurship is seen as unproductive or even destructive (Baumol, 1990), which certainly appears true in those countries where a weak state has allowed these entrepreneurs to gain by privatisation and to secure monopolistic markets or state subsidies (Chepurenko, 1999; Malle, 1996), such as in the Russian Federation, Ukraine, Belarus or the Central Asian republics.

Thus, under transition conditions entrepreneurship takes various forms including nomenclatura entrepreneurship, a whole variety of small business ownership including self employment, part time entrepreneurship and informal sector entrepreneurship. A common underlying principle appears to be networking, which offers a vehicle for gaining access to business opportunities and for resource mobilisation in the unstable environment that pertains in transition conditions. Network connections and blat (a Russian term describing the exchange of mutual favours during Soviet times) played a major role in transforming entrepreneurial activities that existed during the socialist period into capitalist entrepreneurship during transition. As Ledeneva (1998, p. 184) stated: "Blat as a source of new entrepreneurship is twofold: it is a source of the connections which provide access to those state resources drawn upon 
by private business; it also supplies practical skills in keeping personal contacts, fixing things and knowing ways of settling problems". More generally, networks and connections are essential for entrepreneurship under transition conditions, as they are based on mutual trust, thus reducing business risks in an unstable and sometimes hostile economic and political environment.

\section{Characteristics of entrepreneurs and small enterprises under transition conditons: some empirical evidence}

In assessing the distinctiveness of entrepreneurship under transition conditions empirically, it is important to distinguish between countries at different stages of market reform, as well as recognising the importance of different historical traditions. In this regard, selected EBRD indicators may be used to distinguish between countries where market reforms have been slow or not properly installed (such as Ukraine, Belarus, Moldova) and countries where they are more advanced (such as Poland or Estonia). This distinction is used in this section to consider both the characteristics of entrepreneurs and the characteristics of the enterprises that are established, drawing on empirical results from a number of large scale surveys and case studies in various transition countries.

\section{Sources of empirical data}

The original survey data presented in this section are drawn mainly from two studies of SME development in transition economies, in which the authors have been involved. Although the aims of the two studies were different, the surveys included some comparable questions which are the data selected for inclusion here. In both cases, the surveys were conducted through face to face interviews with SME owners/managers, undertaken by local researchers under the supervision of the authors. More details of the data collection and sampling methods used may be found in the respective project reports (Smallbone et al., 1996, 1999a). The case studies referred to in the paper were all undertaken by one (or both of the authors), using semi-structured interview schedules.
Survey One was undertaken in 1995 as part of a study of the survival and growth of manufacturing SMEs in Poland and the Baltic States ${ }^{1}$ (Smallbone et al., 1996). This comprised 600 interviews using a size stratified sampling design. All firms were private, independent and indigenously owned. All had been trading for at least one year and employed less than 100 employees. Survey Two was part of a study of the support needs of SMEs in the Ukraine, Moldova and Belarus, undertaken in $1997 .^{2}$ It comprised a total of 619 face to face interviews with the owners and managers of SMEs drawn from the manufacturing, construction and selected services sectors.

\section{Characteristics of entrepreneurs}

It is well established in the western literature that there are a variety of motives why people start and run small businesses and a similar picture emerges for entrepreneurs in transition economies. Figure 1 summarises the main reason given for starting businesses in the 1997 survey undertaken in the Ukraine, Belarus and Moldova (Smallbone et al., 1999a). It shows that "independence" or autonomy was by far the most common reason given for starting a business, followed by "a desire to boost income" and "personal fulfilment". This pattern of response was not significantly different to that obtained in the survey of 600 owners/managers of manufacturing SMEs undertaken in Poland and the Baltic States in 1995 (Smallbone et al., 1996).

Only a minority of entrepreneurs in the survey undertaken in the Ukraine, Belarus and Moldova referred to unemployment as a reason for start-up and may be considered "reluctant entrepreneurs". However, when dissatisfaction with previous employment is combined with unemployment, approximately 1 in 7 respondents identified "push" rather than pull factors as the main reason for business start-up. At the same time, in attempting to estimate the role of unemployment in new business start-up under transition conditions, it is also necessary to consider the role of hidden unemployment (for example, by forced leave) as well as officially registered unemployed, which means that the actual level of unemployment is often considerably higher than that reflected in the official figures. For example, in Moldova in 1997 


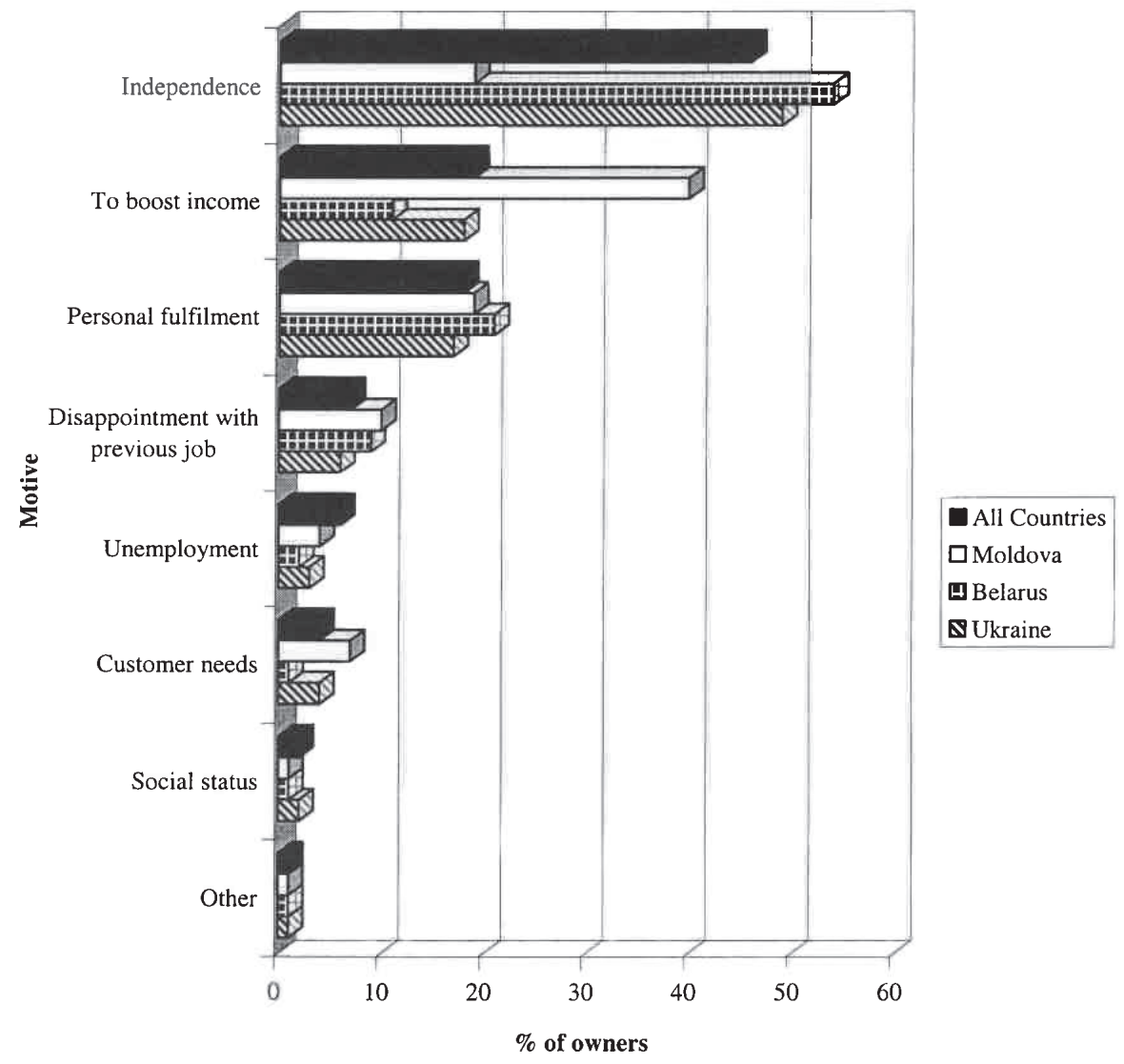

Note: "Total" may exceed $100 \%$ due to rounding.

Figure 1. Main reasons for start-up in Moldova, Belarus and Ukraine.

the number of workers on unpaid leave was estimated to be nearly six times higher than the number of registered unemployed $(1.6 \%$ of the workforce) (IMF, 1998).

Several studies have drawn attention to the high education level of entrepreneurs in transition countries compared with their western counterparts (e.g. Blawat and Dominiak, 1994; Glas and Petrin, 1998; Kuczi and Vajda, 1992). For example, $80 \%$ of surveyed SMEs in the Ukraine, Belarus and Moldova had owners that were educated to university or higher education level, although this varied from $85 \%$ in Ukraine and Belarus to $54 \%$ in Moldova. However, in making such a comparison between transition and western countries it is also important to recognise the highly qualified nature of the population in some former Soviet republics, such as the Ukraine where approximately $90 \%$ of the population have secondary or higher education. A combination of restructuring, recession and a contraction of the defence sector in the 1990s has led to a reduced 
demand for highly qualified labour in such countries, which has encouraged more people of this type to start their own businesses. Interestingly, in a survey of 300 Polish manufacturing SMEs undertaken in 1995 (as part of the larger international comparative study, referred to as Survey One in the previous section), in which $18 \%$ had been established before the start of the administrative reform process in 1981, firms set up after 1988 were significantly more likely to be graduate-led than older firms set up before 1981 (Smallbone et al., 1996).

An example of a graduate entrepreneur is $\mathrm{Mr}$. W who is Director of a research centre in Moscow concerned with analytical and information programmes, which is itself part of a larger research institute. Prior to the commencement of market reforms, W was a research fellow (Ph.D. in political science), claiming to be a frustrated entrepreneur during the socialist period. The reduction of budgets for scientific research in the early 1990s was a push factor that encouraged him to start his own firm in 1992, concerned with data gathering for commercial directory publishing. Located in offices rented from a research institute, the core staff were initially recruited from the founder's former research team. Another example is Mr. X who, frustrated with conditions in Russia in the late 1980s/early 1990s which he described as increasingly difficult for him to make an honest living as a doctor, set up a recruitment agency in Moscow which had successfully established a portfolio of clients consisting mainly of large western companies.

It would appear that under the conditions and turmoil during the early stages of transition particularly, entrepreneurship is one of the few fields where an educated, professional person can satisfy his/her need for creative and satisfying work, whilst obtaining sufficient income for an acceptable standard of living. It remains to be seen whether or not entrepreneurship is seen as an attractive and feasible option for a broader crosssection of the population in these countries as transition proceeds. If it is, then the educational profile of entrepreneurs may change over time, as they are drawn from a wider cross-section of society.

Another distinctive characteristic of entrepreneurship in transition economies concerns previous management and entrepreneurial experience, which influences the nature and extent of the entrepreneur's knowledge base with respect to business activity. In this context, Figure 2 shows, almost three quarters ( $74 \%$ ) of all surveyed owners in the Ukraine, Belarus and Moldova had previous management experience before they started their businesses (Smallbone et al., 1999a). Whilst this is considerably above that in comparable western samples, in most cases, the previous management experience had been obtained in a state-owned organisation rather than in a market driven environment. In fact, only $14 \%$ of all surveyed owners in this study had previous management experience in a private sector company (foreign or domestic), which is not surprising in view of the recent nature of the development of the private sector in countries such as Ukraine, Moldova and Belarus.

At the same time, the previous management experience of those employed in state-owned enterprises may not seem to be the ideal preparation for starting and running a business under market conditions, although some authors stress the experience of "muddling through" during socialism as a necessary requirement for entrepreneurship in uncertain transition conditions (Kusnezova, 1999). Indeed, such a background helps to explain the high level of latent demand for management training among entrepreneurs and SME managers in transition countries. This is linked to a high propensity to recognise management weaknesses in their firms, particularly with respect to those areas of management that are the most closely related to new market conditions: sales and marketing, business planning and financial management.

For example, in the 1995 survey of Polish manufacturing SMEs (referred to previously as Survey One), $64 \%$ of respondents identified management weaknesses in their firm and $78 \%$ expressed an interest in upgrading the firm's management skills (Smallbone et al., 1996). Moreover, this characteristics has been identified in other recent surveys in Bulgaria and the Baltic States (as well as Poland) (Smallbone et al., 1999b). It is also apparent in Ukraine, Belarus and Moldova, where $92 \%$ of surveyed SME owners and managers identified management weaknesses in their firms, the vast majority also expressing an interest in upgrading management skills. Unlike 


\section{Moldova}

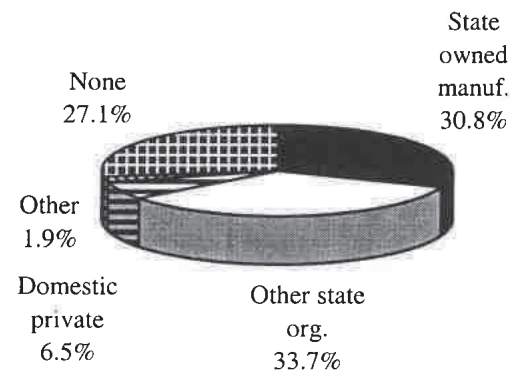

Ukraine

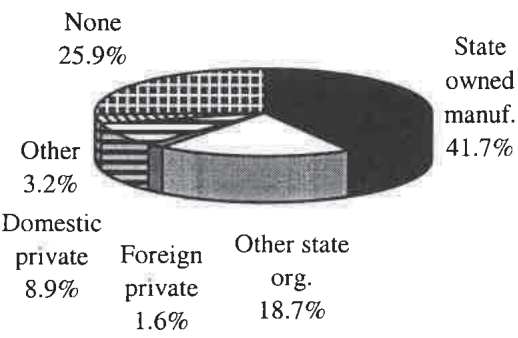

Belarus

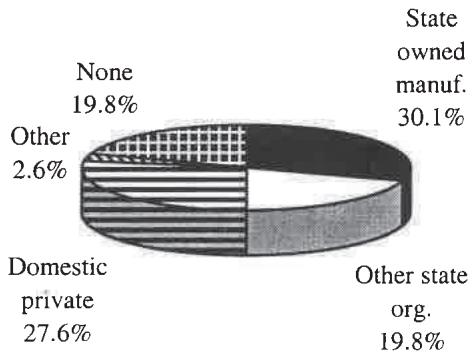

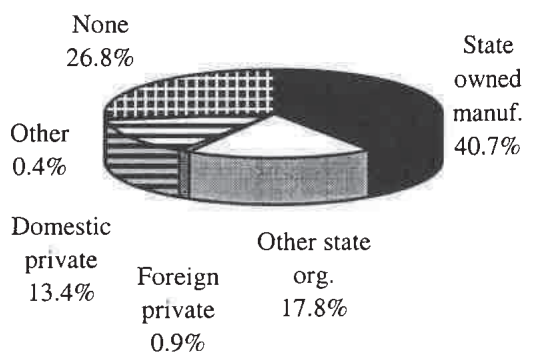

Figure 2. Previous management experience of surveyed entrepreneurs in Moldova, Belarus and Ukraine.

many SME owners and managers in western countries, where there is often a reluctance to seek external assistance in the form of management training (Storey and Westhead, 1996), there does appear to be a higher level of latent demand for appropriate management training in these transition countries. A combination of a lack of previous experience with the demands of the market, together with the effect of higher education in encouraging entrepreneurs to be outward looking, would seem to be contributory factors in explaining this phenomenon.

However, as mentioned in the previous section it is also necessary to take into account the importance of networks and informal connections, the form of which adds a transition-specific dimension to the previous management and entrepreneurial experiences. This can be illustrated with reference to case studies from Moldova and Russia. For example, Mrs. H (the owner/director of a private language school in Kishinev in Moldova) formerly worked in the Ministry of Education where she was responsible for language teaching in the primary and secondary education system. Since she was able to establish working relations with all Kishinev schools as well as with the government administration during this period, she has been able to use these contacts to help to set up her firm, as well as to recruit staff. Government connections assisted her in registering her company, as well as in linking her to a Swedish entrepreneur looking for business opportunities in Moldova, which led the firm to be set up initially as a joint-venture.

A second example is $\mathrm{Mr}$. O who used his political contacts to speed up the privatisation 
process of a state clinic in Kishinev where he worked previously. He initiated the reorganisation and privatisation process himself, although this took more than 3 years from the time of the application until permission was granted because of a general lack of co-operation and constant hassling by minor officials. O claimed that he was only able to complete the privatisation by using his political contacts with the Chairman of the national parliament to put an end to the harassment from "lower-level" administration.

As these cases illustrate, networks and connections are an important resource for business development in transition conditions. In some cases, previous experience and position during the socialist period may contribute to private sector development during the transition period through entrepreneurs being able to still use their "old" networks and connections to help to develop their businesses (Yan and Manolova, 1998). Furthermore, these entrepreneurs are well versed in networking skills which allows them to quickly establish new connections, using informal and social contacts (Ledeneva, 1998).

Finally, a common influence on entrepreneurship in western countries is family background where individuals whose parents were either self employed or business owners have been shown to be more likely to become entrepreneurs than those from families without such entrepreneurial experience. Clearly, in transition economies, where there is little recent experience of private enterprise development, the scope for such an influence is much less than in mature market economies. Whilst empirical evidence supports this, there are differences between countries that reflect different experiences under socialism as well as different pre-war development paths. For example, in the Czech and Slovak Republic, Hungary and Poland in 1993/94, 9\% of surveyed business owners gave "family history" as one of the factors influencing their decision to start up a business (Lageman et al., 1994), whilst in our 1997 survey in Ukraine, Belarus and Moldova, 'family background' was only mentioned as a start up factor by a handful of respondents (Smallbone et al., 1999a).

However, the relationship between family tradition and entrepreneurship in transition countries has to be seen in relation to a sectoral as well as a country-specific context, and also related to the time when the business was first established. More specifically, evidence from Poland and also East Germany suggests that "family tradition" was a common motive for carrying out business activities given by private firms that were set up under communism (Wyznikiewicz et al., 1993; Smallbone et al., 1996; Welter, 1996b), although less common in businesses that were started during the transition period itself. Indeed, in the survey of 300 manufacturing SMEs in Poland undertaken in 1995, "family tradition" was the most common reason for start-up by firms that commenced trading before 1981 (by 42\%) yet was hardly mentioned at all in businesses started after 1991 (just 4\%) (Smallbone and Piasecki, 1996). In other words, the role of family tradition in relation to entrepreneurship is more important in transition countries where certain forms of private entrepreneurship (such as craft activities) were able to exist during the communist period, although even here it was mainly important in the case of businesses set up under communism.

\section{Characteristics of enterprises}

In this section we investigate the nature of the enterprises established under transition conditions, from which the influence of external environmental conditions on the nature of entrepreneurship can be observed. As in western countries, portfolio entrepreneurship is not uncommon in transition countries although the context in which it occurs may be different. For example, in the survey of 619 small business owners in Ukraine, Belarus and Moldova in 1997, 22\% were involved in the ownership of one or more other businesses, with little variation between countries.

Case study evidence points to the role of serial entrepreneurship in representing one of the ways of accumulating the financial resources necessary to build a business in a situation where finance for small firms from formal financial institutions is lacking. This can be illustrated with reference to a small Czech construction enterprise which was set up in 1991 by two construction engineers and a foreman (Lageman et al., 1994). All owners were previously employed in the same state enterprise, although their first experience of entrepreneurship came through self-employment in retailing 
(garments) soon after the transformation began. Income from their initial period of self-employment was used to set up the more substantial construction business later. However, they also continued to trade in clothes as "this is an activity where we know that we can earn money" and because banks were slow in providing credits. A second relevant case study is a small Polish central heating engineering enterprise. In this case, the entrepreneur started with a simple trading activity in 1991-92 that involved buying toys in markets in Belarus, taking them in suitcases across Poland and then selling them in Germany. Through reinvesting the cash generated from this activity, the entrepreneur progressed through owning two retail shops to his current enterprise employing 25 people. Serial entrepreneurship is one of the mechanisms used to mobilise the financial resources required to develop enterprises under transition conditions.

Another feature of some of the enterprises set up in transition countries is their part-time nature. For example, a significant minority of surveyed entrepreneurs in Ukraine, Belarus and Moldova ( $28 \%$ ) had other occupations, suggesting that their business activity was only part-time. The circumstances in which this may arise can be illustrated with reference to the case of a small knitwear manufacturing and retail business in Moldova. One of the two owners started knitting as a parttime activity in 1987 (illegally) while still employed in the defence industry, in order to provide more income for his family. When he found himself unemployed in the early $1990 \mathrm{~s}$, he consequently set up a knitting business as he had already learned the necessary production techniques as well as having some knowledge of and access to markets. Part-time activities in transition countries, especially in those in early stages of transition are often part of a survival strategy made necessary by a lack of social security and low incomes. However, part-time business activity can also provide a route into full-time entrepreneurship, with business development and growth occurring as an individual's circumstances change and his/her confidence grows. Such a phenomenon is not unknown in mature market economies, particularly in circumstances where business ownership is seen as an alternative to unemployment.
However, certain differences in the characteristics of small enterprises that develop are apparent at different stages of the process of market reform. In the early stages of transition, or in countries where market reforms are slow or not properly installed, a lack of stability in the external economic and political environment is often reflected in the characteristics and behaviour of firms at the micro level. For example, survey evidence from Lithuania in the early 1990s suggested that many small firms did not have a single or clear product focus, which meant that entrepreneurs were often engaged in several different activities, some of which were based on individual trade deals (Segal, Quince and Wicksteed, 1995). Moreover, in the early stages of transition, a high proportion of new enterprises are typically set up in trade and services rather than in manufacturing, reflecting a combination of sectoral differences in entry thresholds and uncertainties in the external environment. This encourages entrepreneurs to focus on activities that will generate a quick return on capital employed, rather than those where returns on investment may be slower to materialise (Lageman et al., 1994; Smallbone et al., 1997).

Multiple ownership is another distinctive feature of some of the small enterprises that develop in the initial stages of transition, in former Soviet republics particularly. For example, in a survey of 300 manufacturing SMEs in the Baltic States undertaken in 1995 (referred to previously as Survey One), 54\% of firms had 3 or more owners, $41 \%$ had four or more and $17.5 \%$ had 10 or more (Smallbone et al., 1997). This compared with just $20 \%$ with 3 or more owners in a broadly matched sample of Polish SMEs, where a longer recent tradition of private enterprise development existed and where, unlike the former Soviet republics, fewer small private enterprises had their origins in co-operatives.

Nevertheless, even in countries such as Poland, where a combination of more stable external conditions and a longer recent tradition of private enterprise have contributed to a higher proportion of maturing firms (that are able to contribute to export earnings for example), there are other characteristics that appear distinctive in comparison with SMEs in mature market economies. For example, whilst, as in early stage countries, SMEs 
in Poland dominate in construction, trade and other services, they are also prominent in a range of manufacturing activities. These include food products and beverages, textiles and textiles products, leather and leather goods, wood and wood products and printing (Piasecki et al., 1998). At the same time, Polish manufacturing SMEs are mainly concentrated in traditional sectors rather than in more technology based or innovation focused activities, emphasising price rather than non-price factors in the way they seek to compete in foreign markets. Indeed, this characteristic is not confined to Polish SMEs but was found to be a recurrent feature of the competitive tactics used by SMEs from Bulgaria and the Baltic States as well as Poland, in a recent study of SMEs in the food and clothing sectors (Smallbone et al., 1999b).

\section{The role of government in shaping entrepreneurship under transition conditons}

Whilst emphasising that setting up and developing businesses results from the creativity, drive and commitment of individuals rather than as a result of government actions, the conditions that enable and/or constrain this process are affected by the wider social, economic, political and institutional context, over which the state has a major influence. In this respect, it is important to stress the variety of ways in which government can affect the nature and extent of entrepreneurship in transition countries, rather than narrowly focusing on direct support measures and programmes.

The most important role for the state in relation to entrepreneurship and the development of private business is through its influence on the value placed on enterprise and entrepreneurship within society. Clearly, this is a long term influence and is affected by many factors, such as the characteristics of the education system (at all levels), including both the curriculum and methods of teaching. However, it is also influenced by the stance that government takes with respect to encouraging people to start and develop their own businesses and through the behaviour of politicians and government officials in their dealings with private entrepreneurs (Mugler, 2000). In this context, the empirical evidence from countries in transition (especially in early stages of transition) suggest that many enterprises are set up, survive and sometimes even grow despite government, because of the creativity and drive of individuals and their flexibility in adapting to hostile external environments (see Smallbone and Welter, 1999).

Government laws and regulations define property rights and the rules for exchanging them; they also set the rules for market entry and exit and in support of competition. In other words, they set the basic framework conditions in which entrepreneurship can develop that involves laws relating to property, licensing and the registration of enterprises as well as for bankruptcy, contracts and taxes. In countries where transformation is more advanced, such as Poland or Hungary, the establishment of an appropriate legal system and infrastructure to facilitate the development of markets is more or less complete, and personnel for law enforcement exist. However, in less advanced transition economies a highly inadequate legal system poses a major barrier for entrepreneurs (Radaev, 1994). For example, in Belarus we have found examples of private property being expropriated if individual entrepreneurs become too successful, because neither individuals or companies have a legal right to own property.

Frequent changes in the tax system, combined with a prohibitive tax level and an unpredictable behaviour of state officials, encourage entrepreneurs to shift some or all their activities to the informal economy, or in some cases abroad. In transition countries where market reforms have been slow (such as Belarus, Ukraine or the Russian Federation) the state more typically sees small private enterprises as a potential source of tax revenue rather than as providing one of the bases for transformation to a liberal, market based system. This can be illustrated with reference to a case study of a small consultancy firm in Kiev. The owner referred to frequent inspections by the tax police who always arrive unannounced and on one occasion arrived at his premises in black masks since they have a right to anonymity. The owner mentioned the necessity for him to make a contribution to what he called a "special fund" whose purpose was unknown to him. Although he said that such a payment is not compulsory, if a firm chooses not to make a donation then the visits intensify. Moreover, there are no restrictions on 
the Ukrainian tax authorities with respect to the number of inspections they can carry out on individual entrepreneurs of businesses.

The problem is that in such situations entrepreneurship remains restricted, the number of firms small and their contribution to economic development in terms of jobs, innovation and external income generation rather limited. In addition, hostile and unstable macroeconomic conditions, particularly when combined with low domestic purchasing power, uncertainties over property rights and the slow pace of privatisation, provide little incentive for entrepreneurs to commit themselves to long term projects, forcing them instead to concentrate on the task of surviving. Therefore, in transition countries (especially in those in early stages of transition) the priority need is for a recognition by the state (at all levels) of the role of entrepreneurs in the development of a market-based economy, assuming that market reform is a policy objective. This involves a commitment to strengthen entrepreneurship by establishing the institutional, legal and cultural conditions. It includes basic reforms such as reviewing registration and reporting procedures, reforming the banking and tax system, and steps to eliminate corruption which plays a major role in these countries and seriously impedes entrepreneurship. In other words, promotion of entrepreneurship in transition countries involves redirecting the emerging forms of entrepreneurship into legal and productive sectors of the economy (Baumol, 1990). Whilst there may also be a case, in the short term, for support policies targeted specifically at the development of entrepreneurship, such as training programmes for potential or new entrepreneurs, direct support measures typically have limited impact unless the framework conditions are in place.

\section{Conclusions}

The ten year period that has elapsed since the start of the transformation process has seen a small business sector established in all of the former socialist countries, although both the size of the sector and its qualitative characteristics vary according to the nature and extent of market reforms. As a consequence, whilst some distinctive characteristics (of entrepreneurs and enter- prises) can be identified in comparison with mature market economies, there is also considerable variation between countries. This reflects different starting points in $1989 / 90$, the varying pace of market and institutional reform since then (associated with a varying commitment on the part of government to the reform process), and varying macroeconomic conditions. Whilst it may be tempting to think in terms of a sequential model of entrepreneurship/SME development that is associated with the progression from central planning to a market-based system, the empirical evidence suggests that this cannot be seen as a linear or deterministic path.

As far as the relevance of existing concepts is concerned, our conclusion is that it is the forms of expression of entrepreneurial behaviour that are distinctive in transition economies, reflecting the unstable and often hostile nature of the external environment and the scarcity of certain key resources, particularly capital. Whilst these features may take extreme forms in early stage transition economies, they are not unique to them.

The empirical evidence presented in the paper shows that entrepreneurship under transition conditions takes a variety of different forms, reflecting the challenging role for private enterprise in these countries. The types of entrepreneurship identified include the so-called "nomenclatura" businesses, small firms operating mainly within the formal economy, self employment, part-time businesses and enterprises operating almost or entirely outside the formal sector. Although with the exception of the first mentioned all other types exist under mature market conditions, the specific context in which they have developed (particularly during the early stages of transformation) has implications for their characteristics and pattern of behaviour. Examples include the education and experience of owners which in turn have implications for their attitudes towards management training and the use of external assistance more generally, and differences in the role of family background on the motivation for starting and running businesses.

Not surprisingly, in transition economies, the dominant feature influencing the nature and pace of entrepreneurship and small business development is the external environment, which, in some cases, appears hostile in social, economic and 
political terms. In an unstable and weakly structured environment, informal networks often play a key role in helping entrepreneurs to mobilise resources, win orders and cope with the constraints imposed by highly bureaucratic structures and often unfriendly officials. Moreover, the social context inherited from the former socialist period appears to affect both the attitudes and behaviour of entrepreneurs and the attitudes of society at large towards entrepreneurship.

In emphasising the role of external environmental conditions, it is important to stress that entrepreneurial behaviour in transition countries is strongly influenced by the pace of market reforms. Nevertheless, our empirical results demonstrate that entrepreneurship often develops despite governments. In such a context, even informal businesses that pay no taxes may be regarded as a kind of productive entrepreneurship in a situation where frequently changing legal frameworks, penal levels of taxation, complicated tax structures, as well as unstable macroeconomic situations lead many enterprises to operate at least part of their activities in the shadow economy in order to survive. In such circumstances, the creativity, adaptability and drive of human nature is reflected in the ability of entrepreneurs to develop business activity, despite the hostile external conditions. The flexibility of small enterprises is often referred to in the western literature as one of their potential strengths and sources of competitiveness. In early stage transition economies, extreme flexibility is often a necessary condition for survival for the entrepreneur (in business), whether or not this is manifest in an individual enterprise or through managing a portfolio or series of enterprises.

\section{Notes}

1 This project was undertaken with support from the EU's PHARE ACE Programme (94 0743R).

2 This project was undertaken with support from the EU's TACIS ACE Programme (T95 4139R).

\section{References}

Ageev, A I., M. V. Gratchev and R. D. Hisrich, 1995, 'Entrepreneurship in the Soviet Union and Post-Socialist Russia', Small Business Economics 7(5), 365-376.

Arzeni, S., 1996, 'Entrepreneurship in Eastern Europe: A
Critical View', in H. Brzezinski and M. Fritsch (eds.), The Economic Impact of New Firms in Post-Socialist Countries: Bottom-up Transformation in Eastern Europe, Cheltenham and Vermont, pp. 52-58.

Baumol, W., 1990, 'Entrepreneurship: Productive, Unproductive and Destructive', Journal of Political Economy 98(5), 893-921.

Benacek, V., 1997, 'Private Entrepreneurship and Small Businesses in the Transformation of the Czech Republic', in G. Grabher and D. Stark (eds.), Restructuring Networks in Post Socialism: Legacies, Linkages, and Localities, Oxford: Oxford University Press, pp. 207-241.

Blawat, F and P. Dominiak, 1994, Marketing Consciousness of Industrial Entrepreneurs and Shopkeepers. Presented at the UIC/AMA Research Symposium on Marketing and Entrepreneurship. INSEAD Fontainebleau.

Chepurenko, A., 1998, Die russischen Kleinunternehmen in der zweiten Hälfte der 90er Jahre. Berichte des Bundesinstituts für ostwissenschaftliche und internationale Studien, 45 \& 46, Köln

Chepurenko, A., 1999, 'Die neuen russischen Unternehmer: Wer sie sind, wie sie sind', in H. Höhmann (ed.), Eine unterschätzte Dimension? Zur Rolle wirtschaftskultureller Faktoren in der osteuropäischen Transformation, Bremen: edition Temmen, pp. 139-152.

Curran, J., 1986, Bolton 15 Years On: A Review and Analysis of Small Business Research in Britain 1971-1986, London: Small Business Research Trust.

d'Andrea Tyson, L., T. Petrin and H. Rogers, 1994, 'Promoting Entrepreneurship in Eastern Europe', Small Business Economics 6(3), 165-184.

Dallago, B., 1990, The Irregular Economy: The 'Underground' Economy and the 'Black' Labour Market, Aldershot: Dartmouth.

Dallago, B., 1997, 'The Economic System, Transition and Opportunities for Entrepreneurship', in OECD/CCET (eds.), Entrepreneurship and SMEs in Transition Economies. The Visegrad Conference, Paris: OECD, pp. 103-124.

Frydman, R., K. Murphy and A. Rapaczynski, 1998, Capitalism with a Comrade's Face, Budapest: Central European University Press.

Glas, M. and T. Petrin, 1998, Entrepreneurship: New Challenges for Slovene Women, Paper to the 1998 Babson-Kauffman Foundation Entrepreneurship Research Conference, Gent, May 20-24.

Grabowski, M., 1993, Some Evidence of Small Business Development in East and Central European Countries, Draft paper, Gdansk.

Gustafson, T., 1999, Capitalism Russian-Style, Cambridge: Cambridge University Press.

IMF, 1998, Republic of Moldova: Recent Economic Developments, IMF Staff Country Report No. 98/58, Washington: International Monetary Fund.

Kerblay, B., 1977, La Société Soviétique Contemporaine, Paris: Armand Collin.

Kornai, J., 1992, 'The Affinity between Ownership and Coordination Mechanisms: The Common Experience of Reform in Socialist Countries', in K. Z. Poznanski (ed.), Constructing Capitalism: The Re-emergence of Civil 
Society and Liberal Economy in the Post-Communist World, Boulder, CO: Westview, pp. 97-116.

Kuczi, T. and A. Vajda, 1992, 'Privatization and the Second Economy', The New Hungarian Quarterly 33(126), 77-84.

Kusnezova, N., 1999, 'Roots and Philosophy of Russian Entrepreneurship', Journal for East European Management Studies JEEMS 4(1), 45-72.

Lageman, B., W. Friedrich, R. Döhrn, A. Brüstle, N. Heyl, M. Puxi and F. Welter, 1994, Aufbau mittelständischer Strukturen in Polen, Ungarn, der Tschechischen Republik und der Slowakischen Republik, Untersuchungen des Rheinisch-Westfälischen Instituts für Wirtschaftsforschung, Heft 11, RWI, Essen.

Laky, L., 1984, 'Small Enterprises in Hungary - Myth and Reality', Acta Oeconomica 32(1-2), 39-63.

Ledeneva, A.V., 1998, Russia's Economy of Favours: Blat, Networking and Informal Exchange, Cambridge: Cambridge University Press.

Malle, S., 1996, 'Russian Entrepreneurship and Business in Transition: Towards the Re-Building of State Conglomerates', Journal of International and Comparative Economics 20, 37-64.

Mugler, J., 2000, 'The Climate for Entrepreneurship in European Countries in Transition', in D. L. Sexton and H. Landstrom (eds.), The Blackwell Handbook of Entrepreneurship, Oxford and Malden: Blackwell, pp. 150-175.

OECD/CCET, 1998, Entrepreneurship and Small Business in the Russian Federation, Paris: OECD.

Paradis, P. and A. R. Cervin, 1998, 'Entrepreneurship in the Russian Federation', The OECD Observer 210, 20-22.

Piasecki, B., 1995 'Dilemmas of the SME Sector Promotion Policy During the Transformation Period', in B. Piasecki and D. Fogel (eds.), Regional Determinants of $S M E$ Development in Central and Eastern European Countries, Lodz: Lodz University Press.

Piasecki, B. and A. Rogut, 1993, Self-Regulation of SME Sector Development at a More Advanced Stage of Transformation, Paper presented to the 20th Annual Conference of E.A.R.I.E., Tel Aviv, September.

Piasecki, B. et al., 1998, Business Environment for Running SMEs in Poland and in the EU Countries, Polish Foundation for Small and Medium Enterprise Promotion and Development, Warsaw, Poland.

Radaev, V., 1994, 'On Some Features of the Normative Behavior of the New Russian Entrepreneurs', Problems of Economic Transition 37(8), 17-28.

Scase, R., 1997, 'The Role of Small Businesses in the Economic Transformation of Eastern Europe: Real but Relatively Unimportant', International Small Business Journal 16, 113-121.

Scase, R. and R. Goffee, 1982, The Entrepreneurial Middle Class, London: Croom Helm.

Segal, Quince and Wicksteed, 1995, Small and Medium Enterprises in Lithuania: The Results of a Business Survey, Ecofin Baltic Consulting Ltd., Vilnius.

Smallbone, D. and B. Piasecki, 1996, The Distinctiveness of
SME Development in Poland: Some Empirical Evidence from Manufacturing, Paper presented to the 44th ICSB Conference, Stockholm, 16-19 June.

Smallbone, D. and F. Welter, 1999, The Role of Government in SME Development in Transition Countries, Paper presented at the 44th Conference of the International Council for Small Business, Naples, 19-22 June.

Smallbone, D., B. Piasecki, U. Venesaar, L. Rumpis and D. Budreikaite, 1996, The Survival, Growth and Support Needs of Manufacturing SMEs in Poland and the Baltic States. Final report for Phare (ACE) project (contract no. 94 0743R), Centre for Enterprise and Economic Development Research, Middlesex University.

Smallbone, D., U. Venesaar, L. Rumpis and D. Budreikate, 1997, 'Problems Facing the Development of Manufacturing SMEs in the Baltic States', in N. Hood, R. Kilis and J. E. Vahlne (eds.), Microlevel Studies of the Transition in the Baltic States, Houndsmill, Basingstoke and London: Macmillan.

Smallbone, D., F. Welter, N. Isakova, Y. Klochko, E. Aculai and A. Slonimski, 1999a, Identifying the Support Needs of Small Enterprises in Ukraine, Belarus and Moldova to Develop an Agenda for Policy at National and Regional Levels. Final report for Tacis ACE project (contract no. T 95-4139R), Centre for Enterprise and Economic Development Research, Middlesex University.

Smallbone, D., B. Piasecki, U. Venesaar, K. Todorov and L. Labrianidis, 1999b 'Internationalisation and SME Development in Transition Economies: An International Comparison', Journal for Small Business and Enterprise Development 5(4), 363-375.

Stanworth, J. and J. Curran, 1976, 'Growth and the Small Firm: an Alternative View', Journal of Management Studies 13(2), 95-110.

Storey, D. and S. Johnson, 1987, Job Generation and Labour Market Change, Houndsmill, Basingstoke and London: Macmillan.

Storey, D. and P. Westhead, 1996, 'Management Training and Small Firm Performance: Why is the Link so Weak?', International Small Business Journal 14(4), 13-24.

Szelenyi, I., 1988, Socialist Entrepreneurs, Madison, WI: University of Wisconsin Press.

Welter, F., 1996a, 'Unternehmer in Osteuropa', Berliner Debatte/INITIAL, 100-107.

Welter, F., 1996b, Gründungsprofile im west- und ostdeutschen Handwerk: Eine vergleichende Untersuchung in den Kammerbezirken Düsseldorf und Leipzig, RUFISStudie, Nr. 1/1996, Bochum: Brockmeyer.

Wyznikiewicz, B., B. Pinto and M. Grabowski, 1993, Coping with Capitalism: The New Polish Entrepreneurs, Discussion Paper of the International Finance Corporation, No. 18, Washington, DC: IFC.

Yan, A. and T. S. Manolova, 1998, 'New and Small Players on Shaky Ground: A Multicase Study of Emerging Entrepreneurial Firms in a Transforming Economy', Journal of Applied Management Studies 7(1), 139-143. 